\title{
VILLAGE MOSQUES IN UPPER EGYPT WITH MULTIPLE DOMES COVERAGE IN THE PERIOD OF KHEDIVE ABBAS HELMY II "AL-ATIQ MOSQUE IN ALJABALAW, QENA AS A MODEL (1326 A.H/1909 A.D)"
}

\author{
Zeyada, A. \\ Archaeology dept, Faculty of Arts, Beni Suef Univ., Beni Suef, Egypt \\ E-mail address: ahmed.helmy@art.bsu.edu.eg
}

\begin{tabular}{|c|c|}
\hline Article info. & EJARS - Vol. 11 (1) - June. 2021: 71-85 \\
\hline Article history: & Abstract: \\
\hline Received: 7-10-2020 & The present research explores a pattern of village mosques in Upper \\
\hline Accepted: $28-5-2021$ & Egypt that was rarely adopted, namely mosques with multiple domes \\
\hline Doi: $10.21608 /$ ejars.2021.179498 & $\begin{array}{l}\text { coverage. It highlights the model in a unique pattern in Upper Egypt, } \\
\text { namely Al-Atiq mosque in Aljabalaw, Qena, Egypt. The study ide- } \\
\text { ntifies the reasons behind the use of this pattern in the architecture of } \\
\text { mosques in the village despite its scarce use. It also examines the } \\
\text { architecture of this pattern accurately and the most important features } \\
\text { that distinguish it from the mosques of the main cities in Egypt. The } \\
\text { study documented Aljabalaw mosque in an accurate scientific manner }\end{array}$ \\
\hline Keywords: & and identified its planning principles. Moreover, a descriptive study \\
\hline Mosques of villages & $\begin{array}{l}\text { was done on all architectural and decorative units to analyze and } \\
\text { entrench them where applicable. The study concluded a set }\end{array}$ \\
\hline Multiple domes & results of the reason for adopting this planning in the mosque under \\
\hline Al- Atiq & study for environmental, climatic, or geographic reasons. The founder \\
\hline Aljabalaw & of the mosque might prefer this planning. The study recommends \\
\hline Abbas Helmy II. & $\begin{array}{l}\text { the registration or Al-Atlq mosque in Aljabalaw, Qena as an Islamic } \\
\text { monument. }\end{array}$ \\
\hline
\end{tabular}

\section{Introduction}

The present research paper tackles the architecture of mosques in the villages of Upper Egypt with multiple coverage domes by reviewing a unique model, namely $A l$ Atiq mosque in Aljabalaw, Qena. It is a significant topic because it is an attempt to identify the architecture of mosques in the villages during the reign of Khedive Abbas Helmy II ${ }^{(a)}[1,2]$ based on the pattern, features, and characteristics of mosques with multiple coverage domes. The problem of the study has been defined in having a mosque with a domed ceiling in an Upper Egyptian village in Qena governorate more than $600 \mathrm{~km}$ from the Capital, Cairo. Aljabalaw village was not a state headquarter or an active trade center ${ }^{(b)}$ $[3,4]$ in any Islamic era, especially in the reign of Abbas Helmy II, in which the mosque under study was built. Thus, a key question raises about the reasons for establishing a mosque that adopted the pattern of mosques with multiple domes, despite its rare use in Egypt. The study aims to identify the architecture of the mosques of the village in the reign of Khedive Abbas Helmy II based on the pattern of mosques with multiple domes. It highlights the reason for this pattern in Aljabalaw village. It also explores and documents this distinguished pattern of mosques ${ }^{(\mathrm{c})}$ that did not spread in the villages of Upper Egypt. It identifies the features of this pattern of mosques in the reign of Abbas Helmy II that have not received due atention by researchers. The study adopts a comparative descriptive and analytical approach. 


\section{Overview of Al-Atiq Mosque}

\subsection{Location of the mosque}

Al-Atiq mosque is located in Aljabalaw village to the south of Qena between Naj Orabi in the south and Naj Ashuwaynah in the north, fig. (1-a,b). It was a suburb of Qena and was separated in (1259 AH./ 1843 AD.) entitled Arab Aljabalaw. Since 1262 AH./1846 AD., it has had its present name $[3,4]$. It follows the geographical and administrative division of Upper Egypt. Egypt was divided into Upper and Lower Egypt in the Ayyubid era from Giza to Aswan. While Upper Egypt is currently divided into three sections: The lower level includes Giza, Fayoum, and Beni Suef; Upper Egypt includes Minya, Assiut, and Sohag; the most Upper Egypt extends from Qena to Aswan [5].
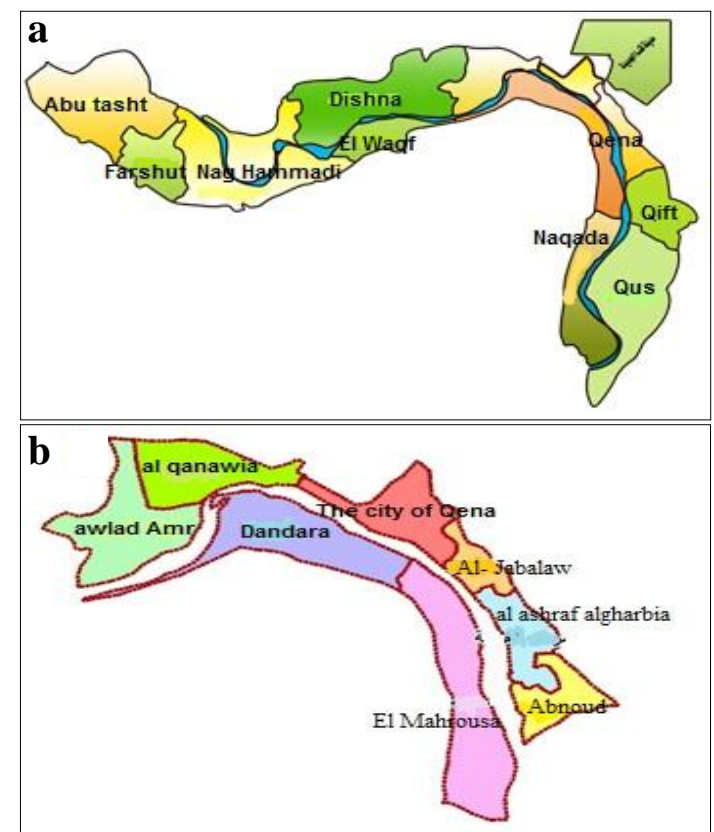

Figure (1) Shows a. Qena governorate localities, b. Aljabalaw village in Qena localities (After, Ministry of planning, follow-up and administrative reform; the online portal of Qena Governorate)

\subsection{The founder of the mosque}

Al-Atiq mosque in Aljabalaw was founded by Sidi Mohamed Ahmed Al-Dandrawi, as registered in its marble foundation text written in Thuluth script ${ }^{(d)}$, fig. $(2-a, b)$. The text reads:

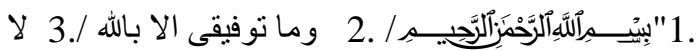

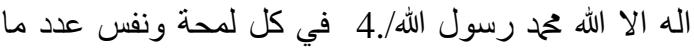

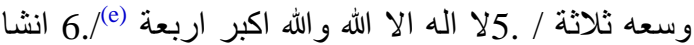

$$
\begin{aligned}
& \text { هذا المسجد سيدنا ومو لانا /7 } 7 \text { محمد أحمد الدندراوى /8 } \\
& \text { سنة } 1326 \text { هـ سنة } 1909 \text { م" مالنا / }
\end{aligned}
$$

[Bism Allah arraћman arraћīm/ wama tawfīqī 'la bi-llah /la 'laha 'la allah Muћamad rasūwl allah/ fī kul lamћa wanfas 'dad ma was'eh thalatha / la 'laha 'la allah wallah akbar arrb'ah/ ansha hada almasjed saīdna wa-mawlana/ Muћamad Aћmad Aldandaraway/ sanat 1326/ sanat 1909 AD.]

Translation: In the name of Allah, the most beneficent, the most merciful/ And my success cannot come except from Allah/ There is no god but Allah and Muhammad is the messenger of Allah/ In every glance and breath as containing as three/ There is no god but Allah four/ This mosque was established by our master and lord/ Mohamed Ahmed Al-Dandrawi/ In 1326 AH. corresponding to 1909 AD.

Al-Dandrawi was a righteous man and a Sufi scholar, known for his goodness and piety. He was the founder of the Dandarawiyya Ahma-diyya $\operatorname{Order}^{(\mathrm{f})}[6,7]$ in Dandara village $^{(\mathrm{g})} \quad[3,4,8]$, Qena in the late $13^{\text {th }}$ H./19 $9^{\text {th }}$ G. and the early $20^{\text {th }}$ century. He was born in (1252 AH./1836 AD.) and attributed to Sultan Al-Youssef ${ }^{(\text {h) }}$ [9] from the desce-ndants of Sharif Idris I, the founder of the Idrisid Dynasty ${ }^{(i)}[10$, 11] in the Arab Maghreb. He memorized the Holy Qur'an by heart and studied religious sciences when he was young.

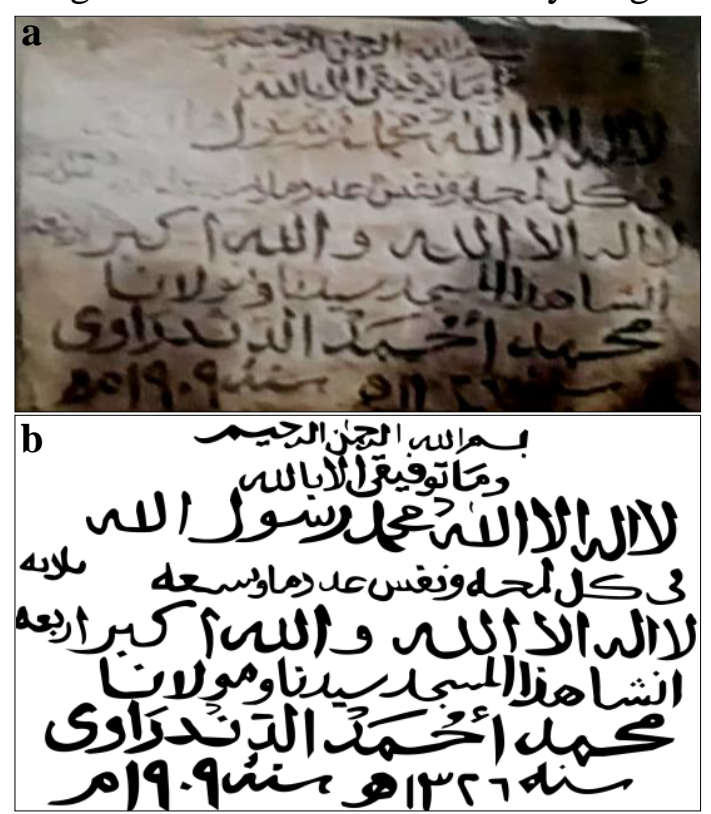

Figure (2) Shows $\underline{\text { a. }}$ the foundation text, $\underline{\mathbf{b}}$. a facsimile of the foundation text 
Then, he moved to Hejaz at the age of twenty from Mecca to Medina and vice versa. He was taught by Ibrahim Al-Rashid who was a disciple of Sheikh Ahmed ibn Idris, the founder of the Ahmadiyya Sufi Order (1215-1291 AH./1800-1874 AD.). He wrote a book entitled "Eaqd al-dari an-nafis fi bad, karamat wa manaqib 'aћmad ibn 'Idris" (Priceless kecklace on some dignities and virtues Ahmed ibn Idris) $[6,7]$. He returned to Dandara and stayed until the age of forty when he traveled to Sudan, Somalia, Aden, and the Levant to deliver lessons. After the death of his sheik (scholar) Rashid, he settled in Medina where he delivered lessons for thirty years until his death (1325 AH./ 1907 AD.) [12]. He was entitled Sultan ${ }^{(j)}$ [13]. The Dandarawiyya Ahmadiyya Order is attributed to Al-Dandrawi. It has its own rituals and costume of loose white clothes and a turban different from the turbans of the people of Upper Egypt $[12,14]$.

\subsection{The foundation date}

The mosque was built in 1326 AH./1909 A.D as inscribed in the Foundation Text. This date may be the date of construction completion because Sidi Mohamed Ahmed Al-Dandrawi died in 1325 AH./1907 AD. Thus, (1327 A.H/1909 A.H) is likely to be a date contemporary to the reign of Khedive Abbas Helmy II.

\subsection{Naming}

The mosque is called Al-Atiq "the ancient" mosque because it is the oldest mosque in the village. Egyptians used to call the oldest mosque of the city or village "AlAtiq", such as Amr ibn al-Aas mosque in Fustat and Al-Omari mosque in Esna (469 AH./1077 AD.). Moreover, Masjed-e Jame (Friday mosque) since the time of Umar ibn al-Khattab was also called the AlOmari or Al-Atiq [15,16].

\section{The Architectural Composition of the Mosque and Annexes}

The mosque consists of three main blocks: Al musalla (prayer area) and annexes, the hall (open courtyard) and its portico, and the service facilities. The mosque occupies the main block in the northwest part, the hall and its portico occupy the southeast part, whereas the service facilities are in the east part of the composition, fig. (3).

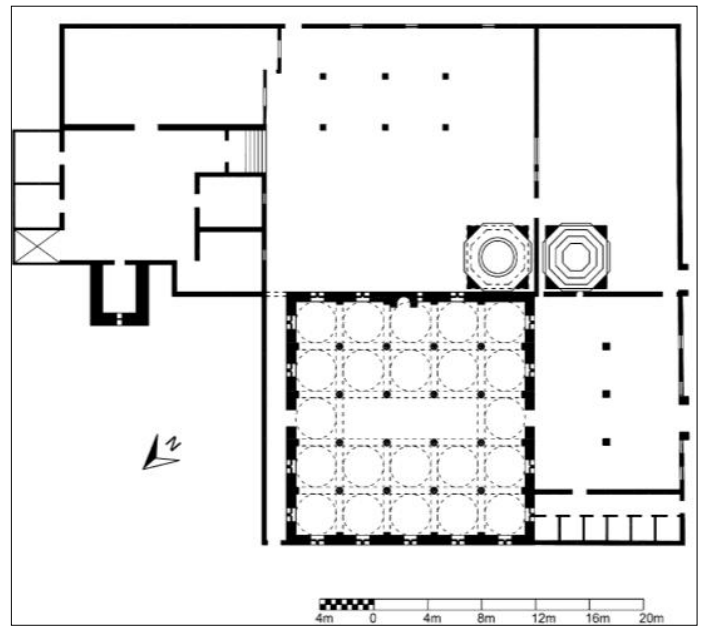

Figure (3) Show the plan of Al-Atiq mosque in Jabalaw

\subsection{Building materials of the mosque and annexes}

Five building materials were used in the construction of the mosque and annexes. Mud-brick (the main building material) was used in the construction of the walls of the mosque and helmets (cupola) of domes. It is cheap, easy to manufacture, and available on the banks of the Nile River. It also gives the buildings warm weather in winter and cool weather in summer $[17,18]$. The local baked brick ${ }^{(\mathrm{k})}$ was used in building the arches, window frames, columns, side supports, and minaret due to its durability and ease of formation required by these architectural elements [18]. Plaster was used for coating the mihrab, its helmet, and columns. Moreover, wood was used in links between arcades, lanterns, minbar, and staircase of the minaret. Iron was used in covering the two windows above the two entrances to the mosque.

\subsection{Al musalla}

\subsubsection{Interior of Al musalla}

The layout of the mosque consists of a square area of $17 \mathrm{~m}$. long. The architect divided it into five aisles using four arcades, whose semicircular arches ${ }^{(1)}$ were of baked brick parallel to the wall of the qibla. The 
arches are based on four cylindrical brick columns with a diameter of $50 \mathrm{~cm}$. On both sides, they are based on raised supports from the northeastern and southwestern walls. These aisles are cut perpendicularly to the qibla wall by five parallel aisles to the wall. Their arches share being based on cylindrical columns with a diameter of $50 \mathrm{~cm}$. They are based on both sides on raised brick supports from the southeast wall and northwest wall. Accordingly, twenty-two square areas $(3 \times 3 \mathrm{~m}$.) are formed, each of which is covered with a semi-circular dome of mud bricks on spherical triangles. The architect linked arcades with wooden tie beams for strengthening, figs. $(3 \& 4)$. The architect handled the middle section of the mosque differently. He treated the three central squares of the mosque by merging them to form a rectangle. He also rose their ceiling to form a Shokshikha (lantern) of wood to allow lighting and ventilation that are not allowed by the domes. This lantern is rectangular $(3 \times 9 \mathrm{~m}$.) and extends transversely parallel to the qibla wall. It is worth noting that the architect handled the prevailing climate by making the lantern parallel to the qibla wall, not perpendicular to attract the most possible lighting and ventilation to the interior space of the mosque. The lantern $(80 \mathrm{~cm}$. high) was wooden. Its four sides are interrupted by interlaced windows of transparent wood. Despite having this architectural treatment of the lantern in Abdi Bey mosque in Cairo (1071 AH./1660 AD. ${ }^{(m)}$ [19], it is different in Al-Atiq mosque in Jabalaw as it was implemented transversely unlike being longitudinally in most of the mosques of Egypt in the $19^{\text {th }}$ century $\mathrm{AD}$, such as the lanterns of Abu Daraa mosque in Cairo (1217- 1218 AH./1801-1802 A.D), Hassan Pasha Taher mosque in Cairo (1224 A.H / 1810 A.D), Jawhar Al-Mu'aini mosque (1229 AH./ 1814 AD.), Suleiman Pasha al-Faransawi mosque (1276-1277AH./1859-1860 AD.), Al-Qabr Al-Tawil mosque (1285 AH./ 1867 AD.), Muhammad Bey mosque (1292 AH./ 1874 AD.), Abdulaziz Al-Derini mosque
(1291-1292 AH./1873-1874 AD.), AlBarbari mosque (1307 AH./1888 AD.). The lantern was designed transversely in many mosques of Egypt in the $19^{\text {th }}$ century, e.g., Al-Jawhary mosque (1262-1265 AH./ 1845-1848 A.D) and Ashmawi mosque (1266-1267 AH./1846-1247 AD.). However, these two models do not have adequate lighting via the windows. They have a free façade overlooking the street with windows. They also have open windows on the haram (courtyard) of the mosque. Thus, the lantern was made parallel to the qibla wall to attract as lighter and ventilation as possible to the interior of the mosque. These motives and reasons are similar in Al-Atiq mosque in Alja-balaw for having a transverse lantern, i.e., the lack of ventilation and lighting. Another reason was that the method of covering with domes. The lantern was transverse in Hussein Pasha Abi-Asba mosque in Cairo (1288 AH./1870 AD.) despite the multiple façades and windows of the mosque. The architect might want to increase the ventilation and lighting of the mosque [20].

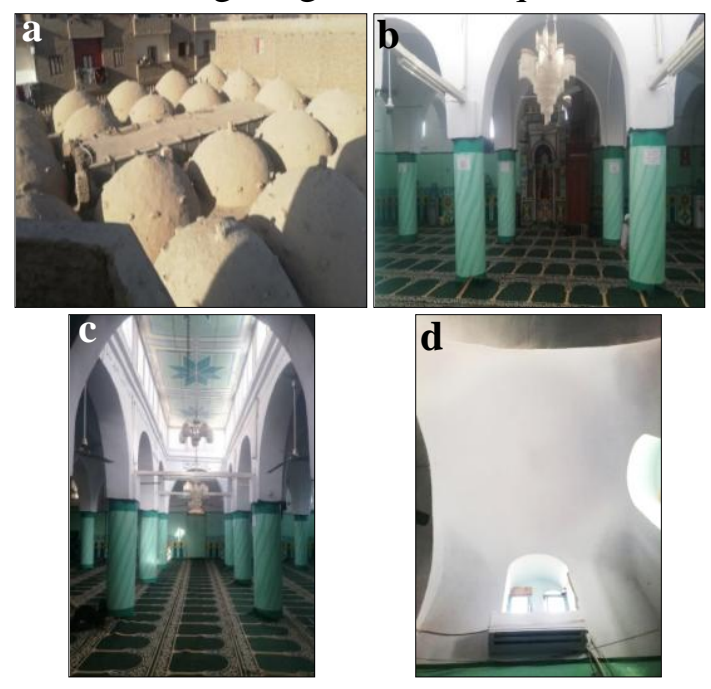

Figure (4) Shows a. the calling of the mosque, $\underline{\mathbf{b}}$.

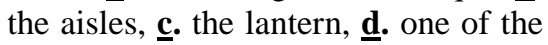
domes of the mosque

The mihrab is in the middle of the southeastern wall, which is a semicircular apse topped with a conch-shaped apex overlooking the interior by a semicircular arch with a lobed façade on a pair of integrated cylindrical columns on both sides. It rests on a base of $1 \mathrm{~m}$. high. The architect gave the mihrab's 
façade a memorial nature by projecting it along the qibla wall. The projected part is decorated with a row of floral windows. Moreover, the parts of the apse and the façade are decorated with a modern painting and various geometric elements, such as the three-pointed leaf, fig. (5-a). The minbar (pulpit) is to the right of the mihrab. It consists of a rectangular base $(2.5 \mathrm{~m} . \times 90$ $\mathrm{cm}$.) of $35 \mathrm{~cm}$. high. It is decorated with a rectangular transverse-stripe from superimposed small wooden parts with a fret. The front part of the base of the moqadem door (minbar door's entrance) of $70 \mathrm{~cm}$ wide and $2.2 \mathrm{~m}$. high. It is arched with a lobed decorative arch and closed with two shutters (one of them is $0.35 \times 2.2 \mathrm{~m}$.). Each shutter is divided into three parts: The square lower and the upper parts $(30 \mathrm{~cm} \times$ $30 \mathrm{~cm}$.) using superimposed small wooden parts with a superimposed eightfold in the space and a rectangular middle section (0.30 $1.2 \mathrm{~m}$.) occupied with superimposed geometric shapes of hexagonal stars. This door is topped by a rectangular area with a painted tape [21] that reads:

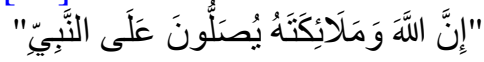

[Inna Allah wa malaikatahu yusalu 'ala nabi] (Indeed, Allah confers blessing upon the Prophet, and His angels [ask Him to do so]). The decorated arch is topped by a two-level muqarnas (stalactite) top, ending with a row of fine and hollow wooden windows in the form of a five-pointed leaf, fig. (5-b,c).

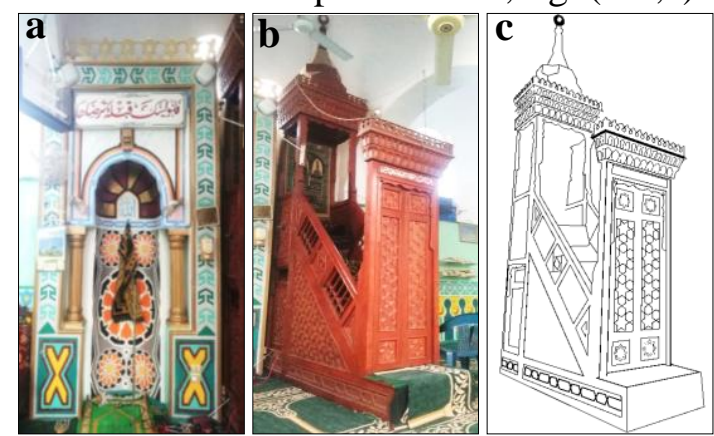

Figure (5) Shows $\underline{\text { a. }}$ mihrab, $\underline{\mathbf{b}}$. minbar, $\underline{\mathbf{c} .}$ minbar facsimile

The moqadem door opens on the șadr of the minbar (front part), which consists of five steps of $25 \mathrm{~cm}$. high each. On both sides, it has two wooden balustrades, each of which is divided into five wooden panels; two right-angled triangles and three squares with wooden barameq. The middle panel is decorated with a mafrouk of superimposed small wooden parts. The staircase ends with a square seat (mak'ad) surrounded by four wooden columns that form the djawsaq. Every two columns are connected from the top with a decorative arch similar to the one above the opening of the muqadam door. Moreover, the arches are three-levels solid wooden blocks of fine muqarnas surrounded from the top by a row of wooden windows that resemble those above the mass of the muqadam door. Upon this block, there is the top of the minbar, which is a square base with rinsed corners from the top to turn into an octagonal area. Upon this area, a conical shape moves up (an Ottoman style). In its end, a pair of rounded tafateeh rising is fixed. This shape ends with a crescent, fig. (5-b,c). Below the khateeb seat, there is a pair of rawda door topped by decorative lobed arches that resemble those at the top of the muqadam door and the djawsaq surrounding the seat. Each door is $70 \mathrm{~cm}$. wide and $1 \mathrm{~m}$. high. It is closed by a wooden shutter, decorated with superimposed small wooden parts that take the shape of an eight-pointed star. The craftsman left a window at the top of the rawda door for ventilation and lighting, fig. (5-b,c). The two sides of the pulpit "risha" have the shape of a right-angled triangle, on which geometric shapes of six-pointed stars through a superimposed small wooden part were implemented. The mosque is accessed through two entrances on one axis in the middle of the southwestern and northeastern walls, each with a rectangular entrance of $25 \mathrm{~cm}$. deep. The door opening consists of two rectangular levels of $1.25 \mathrm{~m}$. wide and $2.2 \mathrm{~m}$. wide, closed by two simple wooden shutters, fig. $(5-b, c)$. The upper part of the door opening is a window with a semicircular arch. Its façades are covered with iron grills with radiant geometrical formations from the bottom of the arch. The northeastern entrance overlooks a narrow street to enter from both sides with an entrance with a segmental arch that ends on the southern side with an open square area (the area of performing the rituals of the Ahmadiyya order that will be discuss- 
ssed later). Each entrance is surrounded by two rectangular windows in the upper third of the façade, taking the form of simple Qandaliya. Each window consists of two adjacent rectangular windows of $40 \mathrm{~cm}$. wide and $1 \mathrm{~m}$. high. They are arched by semicircular arches and topped by a closed circular skylight. A portico was added in front of the southwestern façade of the mosque. Moreover, the entrance in the middle of this façade links the mosque and the annexes in this modern area. It was originally the main entrance to the mosque and overlooked the main street of Al-Jablaw village, while the second northeastern entrance was between the mosque and the aforementioned vestibule. Both entrances are topped by a semicircular window covered with iron. Additionally, the walls of the mosque are covered with a layer of modern mortar and modern oil paintings. The architect opened five similar windows in the northwestern wall and four windows in the southeastern wall because the mass of the minaret advancing the south side of the eastern wall prevented having the fifth window. The window above the mihrab is on a more elevated plane. It is single and lower than the other windows, fig. (6-,b,c,d,e,f).
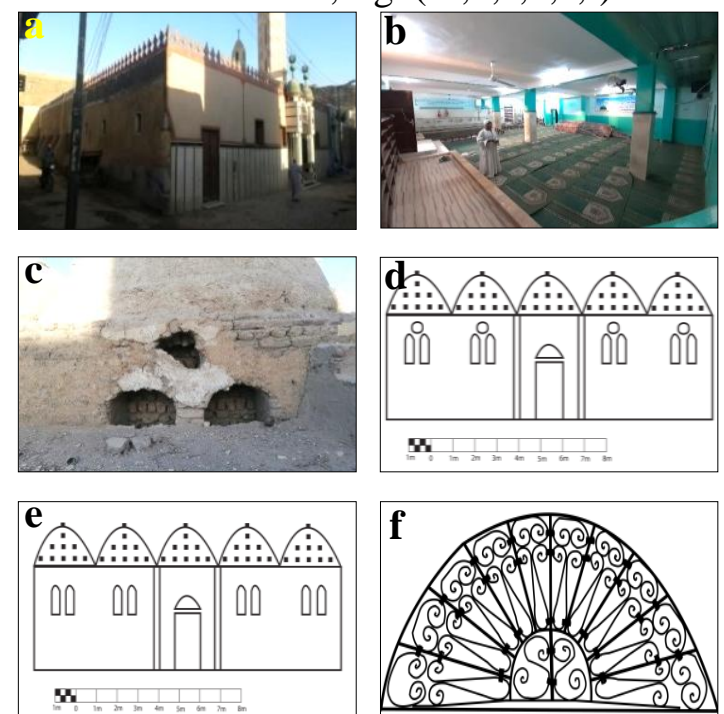

Figure (6) Shows a. the southwestern and northwestern façades, $\underline{\mathbf{b}}$. the southwestern façade and its portico, c. qandaliya, d. the southwestern and northeastern façades before modification, e. the southwestern and northeastern façades after modification, $\mathbf{f}$. the facsimile of the window above the entrance

\subsubsection{Façades of al musalla}

$\mathrm{Al}$ musalla has four free façades: southwestern, northeastern, southeastern and northwestern

\subsubsection{The southwestern and north- eastern façades}

Each façade is $18 \mathrm{~m}$. long and about $4 \mathrm{~m}$. high. They were built of mud of $1 \mathrm{~m}$. thick ${ }^{(\mathrm{n})}$, except for the window frames that were built with baked brick ${ }^{(0)}$. They are covered with a layer of modern mortar. They end with plaster small windows in the form of a fivefold leaf. In the middle of each façade, the architect opened an entrance on one axis of $25 \mathrm{~cm}$. deep. The opening of the door consists of two levels: The lower is a rectangle of $1.25 \mathrm{~m}$. wide and $2.2 \mathrm{~m}$. high. They are closed with simple wooden shutters. The upper part of the door opening is a window with a semi-circular arch whose façades are covered with iron grills from the lower part of the arch. The architect was keen on covering the façade of this area in this manner to fulfill the function of the lighting shaft. The southwestern entrance is the main entrance to the mosque. The area in front of the two entrances is a courtyard. It overlooks the main street. Moreover, a portico, a toilet, and a modern meda'a (ablution area) were added in the front area of the southwestern entrance to the mosque. A modern house was built in front of the northeastern entrance. Thus, the southwestern entrance connects the portico, the ablution area, the toilet, and the mosque, leaving a corridor in front of the northeastern entrance to separate the northeastern façade from the modern house. The architect opened two entrances: One overlooking the northwest façade and the other overlooking the mosque courtyard. Each of the two entrances is surrounded by two simple qandaliyat windows in the upper third of the façade. It has two adjacent rectangular windows of $40 \mathrm{~cm}$. wide and $1 \mathrm{~m}$ high with semicircular arches topped by a newly blocked circular skylight, fig. (6-a,b,c,d,e,f).

\subsubsection{The southeastern façade}

It is $20 \mathrm{~m}$ long and $4 \mathrm{~m}$ high. It overlooks the courtyard of the mosque. It was built with mud bricks, except for window frames 
that were built with baked brick. It is covered with a layer of modern mortar and ends with plaster windows in the form of a modern five-pointed leaf. On the eastern side, the architect opened a $90 \mathrm{~cm}$. wide entrance opening, $2.2 \mathrm{~m}$. high with a segmental arch, leading to a corridor (vestibule). Additionally, he opened three simple qandaliya windows at the upper third of the façade whose blocked skylights resembled those of the aforementioned southwestern and northeastern façades. At the top left of the mihrab, he opened a window of 40 $\mathrm{cm}$. wide and $90 \mathrm{~cm}$. high topped by a semicircular arch. It is higher than the other windows because of being on the top of the mihrab where no enough space is available to distinguish the mihrab. The architect supported the façade with three sloping brick pillars. In other words, he introduced a structural treatment in distributing those pillars by placing them along the arcades whose arches move in a direction perpendicular to the qibla wall to absorb the strength of the inner arches' rafs (strong movement). This façade overlooks the mosque's courtyard. Besides, modern statements were inscribed at the upper level of the façade to express the rituals of the Dandrawi Ahmadiyya order, fig. $(7-a, b, c)$.
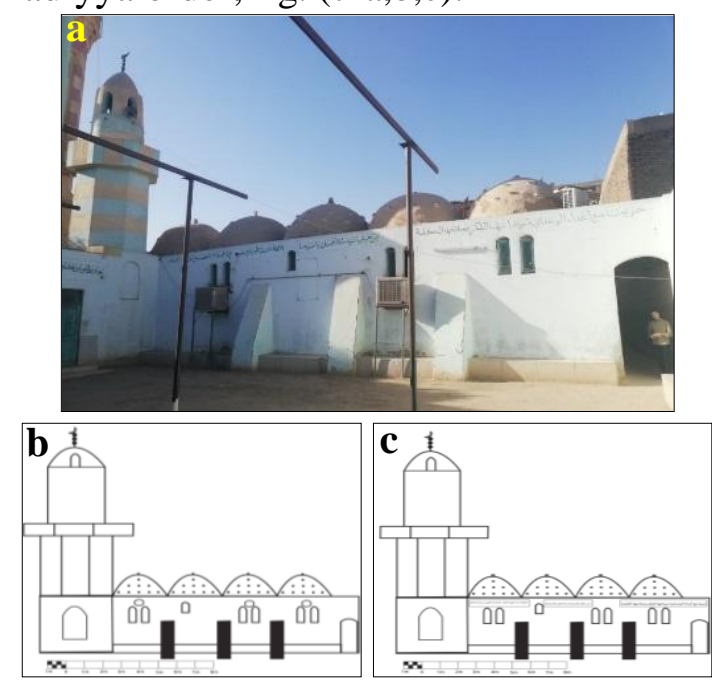

Figure (7) Shows $\underline{\mathbf{a}}$. southeast façade, $\underline{\mathbf{b}}$. southeast façade before modification, $\underline{\mathbf{c}}$. southeast façade after modification

\subsubsection{The northwestern façade}

It is $20 \mathrm{~m}$. long and $4 \mathrm{~m}$. high. It was built with mud bricks, except for window frames that were built with baked brick. It is covered with a layer of modern mortar. It ends with plaster windows in the form of a modern five-pointed leaf. The architect raised four pillars of brick to the outside of $1 \mathrm{~m}$. long and created three sections of the façade. He opened three simple qandaliya windows in the upper third of the middle section similar to the aforementioned windows. In the two side sections of the façade, he opened one simple qandaliya window. Moreover, he supported the façade with four sloping brick pillars resembling those of the southeastern façade along the arcades whose arches are perpendicular to the qibla wall to absorb the strength of the inner arches' rafs. At the farthest side to the north of the façade, the architect created an opening of $90 \mathrm{~cm}$. wide and $2.2 \mathrm{~m}$. high closed with a new iron door. This entrance leads to the northeastern corridor to the courtyard, fig. (8-d,e,f).
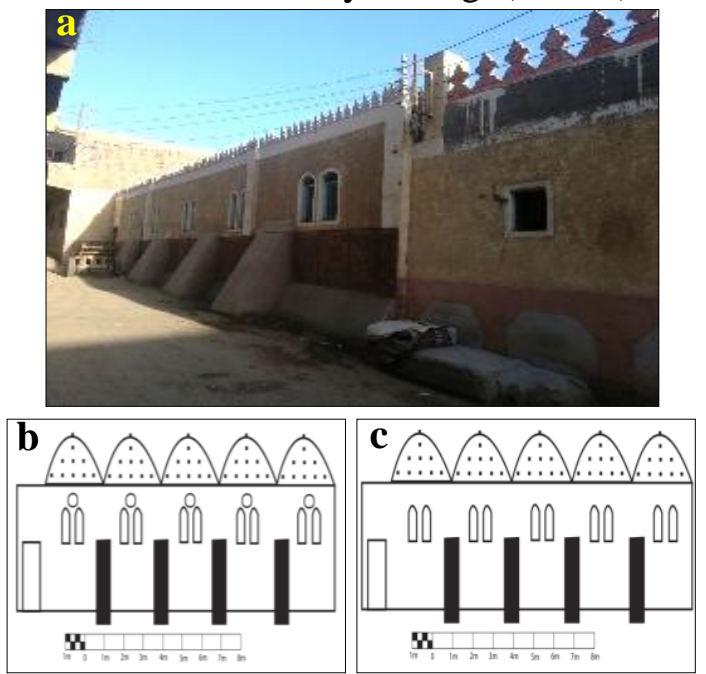

Figure (8) Shows $\underline{\text { a. }}$ northwest façade, $\underline{\mathbf{b}}$. northwest façade before modification, $\underline{\mathbf{c}}$. northwest façade after modification

\subsubsection{The minaret}

The old original raised minaret occupies the southern side of the mosque. Architecturally, it merges with the qibla wall from the outside. It was built of baked brick and covered with a layer of mortar. It comprises a base and two floors. The base has a square projection of $3.9 \mathrm{~m}$. long and $4 \mathrm{~m}$. high. It is a solid block starting from the level of the façade's floor. A solid rectangular apse is in the southwestern and southeastern sides of the base arched with a trefoiled arch of $10 \mathrm{~cm}$. deep and $1.2 \mathrm{~cm}$. high. A solid rectangular apse is in the northeastern sides of the base arched with a semicircular arch 
of $10 \mathrm{~cm}$. deep and $1.2 \mathrm{~cm}$. high. Besides their importance, these decorative apses help reinforce the base of the minaret. The first floor starts with the level of the mosque's ceiling. It is octagonal; each side is 1.3 $\mathrm{m}$. long and $4.25 \mathrm{~m}$. high. In the middle of the side facing the ceiling of the mosque, the architect created an entrance opening of $50 \mathrm{~cm}$. wide and $1.5 \mathrm{~m}$. high arched with a semi-circular arch. The rest of the façades of this floor are solid. The second floor of the minaret has a cylindrical projection. The diameter of its lower part is $3.5 \mathrm{~m}$. It is $4.25 \mathrm{~m}$. high. It is narrower as it moves up. It is covered with a small semi-circular dome whose stand has four tafateeh and ends with a crescent. Six windows that are $45 \mathrm{~cm}$. wide $1 \mathrm{~m}$. high are opened at the bottom of the dome. Each one of them has a semi-circular arch. An entrance of $50 \mathrm{~cm}$. wide and $1.5 \mathrm{~m}$. high with a semi-circular arch is in the lower section of this floor. It a single-balcony space, which separates the two floors of the minaret and takes an octagonal body. Each side is $1.6 \mathrm{~m}$. long. The octagonal body is surrounded by a brick balustrade of $1 \mathrm{~m}$. high. The upper part of the second floor of the minaret was designed in the form of a jawasaq ${ }^{(\mathrm{p})}$ [22] of four rectangular windows arched with semicircular arches. A fahl (structural support) of baked brick is in the middle of the minaret in which the steps of the ascending staircase to the balcony of the minaret and its upper level are fixed. In this staircase, tree trunks stacked and covered from above with a layer of mortar were used, fig. (9-a,b,c,d).
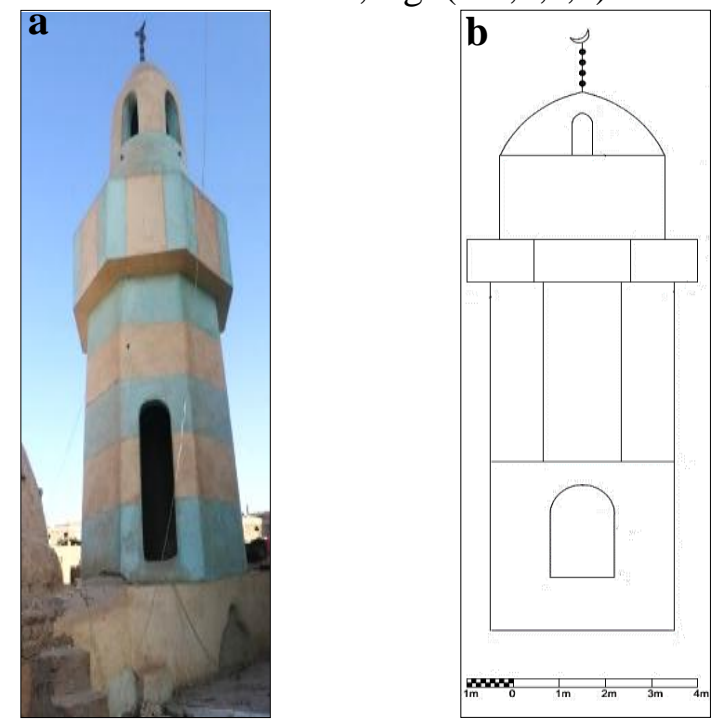
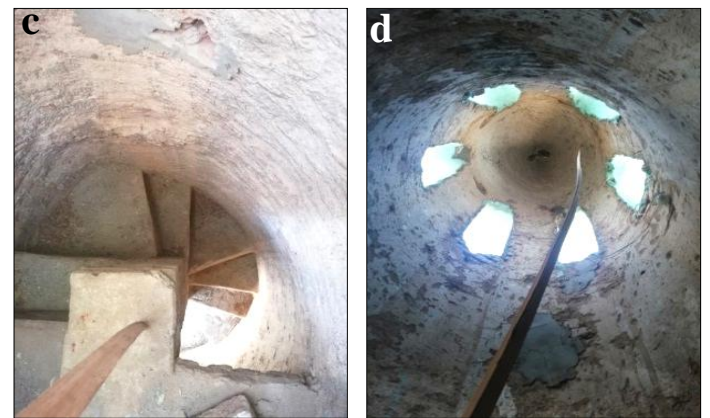

Figure (9) Shows $\underline{\mathbf{a}}$. the body of the minaret, $\underline{\mathbf{b}}$. the southeastern façade of the minaret, $\underline{\mathbf{c}}$. the stairs of the minaret, $\underline{\mathbf{d}}$ the dome of the minaret djawasaq.

This minaret was modeled after the architectural style of the minarets of upper Egypt in terms of material and simple design, such as the minarets of Al-Omari mosque in Esna (474 AH./1081 AD.) and Al-Omari mosque in Asfun, Bahjoura, and Hiu (4-7 H./1013 G. centuries) [16], which did not differ from some minarets of the villages of lower Egypt, such as the minarets of Sidi Fakhr El-Din mosque in Toukh Mazyad village, Al-Santah locality (1330 AH./1920 AD.) and Sidi Abdullah bin Al-Hareth mosque in Saft Trapp village, Al-Mahalla Al-Kubra (1332 AH./1914 AD.) [23]. It is noticed that the end of the minbar of Al-Atiq mosque in Jabalaw was modeled after the Ottoman style (the top takes the shape of a pencil), while the end followed a local style ending with a dome. The same method of contrast and difference of the minbar and minaret in the same mosque was implemented in some mosques of the Ottoman era, such as the Mahmudiya mosque in the citadel square, Cairo (975 AH./ 1567 AD.) whose minbar followed the local style of a bulbous dome and the minaret followed the Ottoman style (the top takes the shape of a pencil). Al-Atiq mosque in Jabalaw is similar to Abdi Bey mosque in Cairo (1071 AH/1660 A.D) in terms of the plan with multiple domes, the minbar that ends with a bulbous dome (a local style), and the minaret that ends with an Ottoman style-top (taking the shape of a pencil).

\subsubsection{The courtyard}

This courtyard is in front of the southeastern side of the mosque behind the qibla wall, taking the same width. It is a 
rectangular cross-sectional area that measures $20 \mathrm{~m}$. long from the south to the east and measures $13.5 \mathrm{~m}$. from the north side to the south. It is accessed through three new entrances. The first entrance is in the northwest (the qibla wall of the mosque is the northwestern wall of the courtyard) and measures $90 \mathrm{~cm}$. wide and $2.2 \mathrm{~m}$. high. It has a segmental arch to a corridor (vestibule) leading to the modern entrance to the mosque on the northwestern façade. The second entrance is in the southwest and measures $1.8 \mathrm{~m}$. wide and 2.2 $\mathrm{m}$. high. It is closed with a modern twoshutter door. The third entrance is on the southeastern side and leads to the portico of the courtyard. It measures $1.4 \mathrm{~m}$ wide and $2.2 \mathrm{~m}$. high. It is closed with a modern wooden door. The multiple entrances correspond to the function of the space dedicated to performing the group rituals of the Ahmadiyya order, to which Sidi Mohamed Ahmed Al-Dandrawi belongs, fig. (10-a,b).

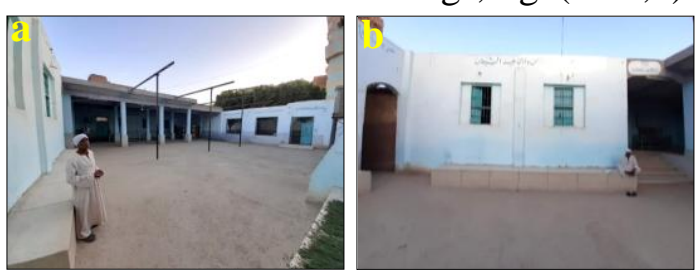

Figure (10) Shows a. the courtyard (alsaha) and its portico, $\underline{\mathbf{b}}$. the courtyard and façade of service facilities

\subsubsection{Service facilities}

They are accessed through the aforementioned courtyard. The entrance leads to a rectangular reception area $(9.5 \mathrm{~m} . \times 1.95 \mathrm{~m}$.). In the northeastern wall, the architecture created three entrances. While the first (a store) and the second (a kitchen) overlook a rectangular area, the third opens fully to a modern rectangular lantern. In the northwestern wall of the reception unit, the architect created two entrance openings. The first is $80 \mathrm{~cm}$. wide and $2 \mathrm{~m}$. high, it is arched by a segmental arch that opens to a cell from the time of construction that was dedicated to Sidi Muhammad Ahmed AlDandrawi. The second leads to a modern cell that takes the shape of the letter $L$ and has a window that overlooks the courtyard.
In the southwestern wall, the architect created an entrance that connects the square with the living units. The entrance leads to a modern rectangular cell with a window overlooking the courtyard. The architect made a modern rectangular cell with two windows overlooking the portico in the southeast wall, figs. (3-4). From speciallized point of view, it could be noted that the cell of Sidi Mohamed Ahmed Al-Dandrawi is the most important components of these facilities. It is a rectangular area $(3.68 \mathrm{~m}$. $\times 2.8 \mathrm{~m}$.) built of mud brick. Its walls are $90 \mathrm{~cm}$. thick, covered with a semi-barrel vault of baked brick. The walls and the vault are covered with clay mortar and modern painting. The cell has an entrance opening of $90 \mathrm{~cm}$. wide and $2.2 \mathrm{~m}$. high. The entrance opening is narrower from the outside and measures $80 \mathrm{~cm}$. wide and $1.8 \mathrm{~m}$. high. It is arched with a segmental arch. The architect made a window of 40 $\mathrm{cm}$ window $80 \mathrm{~cm}$. high for lighting and ventilation, fig. (11-a,b).

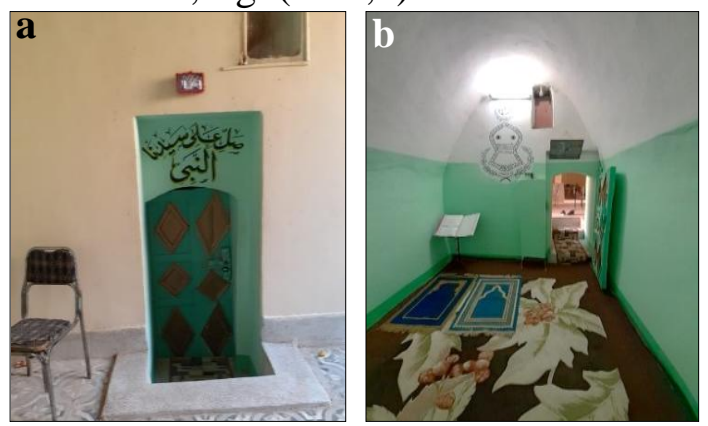

Figure (11) Shows a. the entrance to Sidi Mohamed cell, b. Sidi Mohamed cell

\section{Discussion}

Analyzing and discussing the layout of Al-Atiq mosque in Jabalaw shows that it consists mainly of a square area divided into twenty-two square areas by four crossed arcades covered in hemispherical domes with a semicircular sector that has a transverse lantern in the middle. The architect created this sector in the middle of the ceiling of the mosque to occupy three square areas. This layout has been known in the architecture of mosques in Egypt since the Ikhshidid era with varying building materials used and some details and treatments, 
such as the layout of the Mashhad of alTabatba (334 AH./945 AD.), fig. (12-a,) whose layout consists of an area that divides the mosque into three intersecting aisles forming nine square spaces covered with a spherical dome. This planning continued during the Fatimid era in the architecture of the Mashhad of the Seventy-seven Wali in Aswan $\left(5^{\text {th }}\right.$ H./10 ${ }^{\text {th }}$ G. century), fig. (12b), which closely resembled the layout of the Mashhad of al-Tabatba and Almashad Alqibly in Aswan (534 AH./1139 AD.), fig. (12-c) that has six domes [16,22,24]. Except for the few models in which vaulted ceilings were used with different planning, such as the Al-Aqmar mosque in Cairo (519 AH./1125 AD. $)^{(\mathrm{q})}$ [22], no layout, to the author's knowledge, of religious facilities, especially mosques, have been discovered to follow the pattern of Aljabalaw mosque throughout the Ayyubid and Mamluk eras in Egypt. During the Ottoman era in Egypt, this layout was used in a few models that were influenced by the layouts of religious architecture during that period $^{(\mathrm{r})}[25,26$, 27]. This layout was used in the architecture of The Takiyya of Qasim Pasha Mosque in Alexandria (before 1029 AH./1620 AD.), fig. (12-d) with two intersecting aisles that formed four areas covered with domes. Moreover, this layout moved to Cairo where it was used in the planning of Abdi Bey mosque in Cairo (1071 AH./1660 AD.), fig. (12-e), which consists of three intersecting aisles of nine areas covered with domes whose layout restored similar schemes to the aforementioned Ikhshid and Fatimid religious establishments with the introduction of a new treatment. This layout replaced the coverage of the central square area with a lantern inserted later in the century $\left(13^{\text {th }}\right.$ $\mathrm{H} / 19^{\text {th }} \mathrm{G}$. century) $[19,24]$. It is a climatic treatment to introduce the greatest amount of ventilation and lighting for the interior space. The architect designed the middle section of the mosque's ceiling in the form of a lantern from the beginning. In the layout of Mustafa Bey (Abu Ali) mosque in Alexandria (1117-1121 AH./1764 AD.), fig. (12-a) consisting of two intersecting aisles that formed four areas covered with domes, similar to the layout of The Takiyya of Qasim Pasha mosque [28]. Additionally, the mosque of Sidi Mohamed al-Mashid in Rashid (1187 AH./1764 AD.) adopted the plan of domed coverage [29].

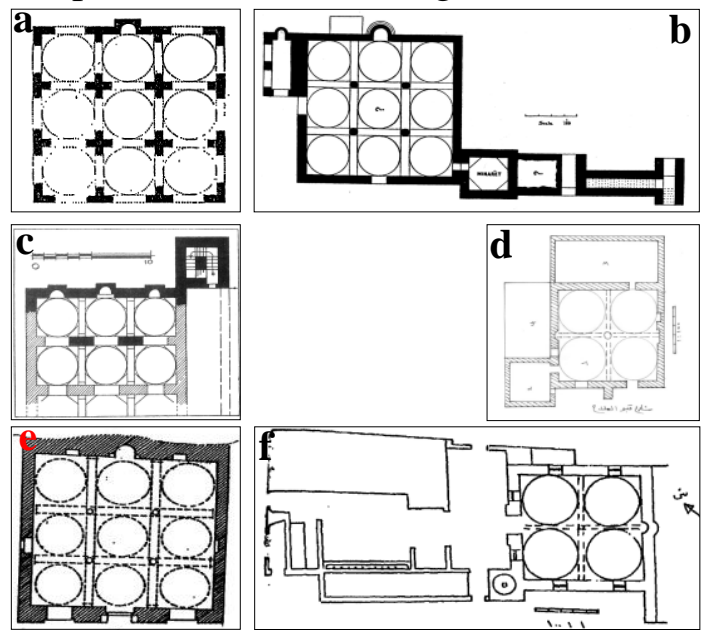

Figure (12) Shows a. plan of the cenotaph of al tabatba (Criswell), $\underline{\mathbf{b}}$. plan of the cenotaph of seventy-seven wali (Clarke), c. plan of the tribal cenotaph (Moniret), d. plan of Qasem Pasha mosque (Duqmaq), e. plan of Abidy bey mosque (Hartiz Bey), f. plan of Mostafa Bey mosque (Duqmaq)

There are many examples of this planning in Islamic architecture in the Levant and Morocco, such as the planning of the Balkh mosque in Afghanistan $\left(3^{\text {rd }} \mathrm{H} / 9^{\text {th }} \mathrm{G}\right.$. century), fig. (13-a), which is the oldest example of this planning, the Tarmez mosque (423 AH./1032 AD.), fig. (13-b), and Kalbarja mosque in India (691 AH./1367 AD.) [30, 31]. This planning was also adopted in Turkey in the Ottoman era, including the grand mosque in Devriji, Eastern Anatolia (626 AH./1228 AD.), the great mosque (Ulu Cami) in Bursa (799-803 AH./13961399 AD.), fig. (13-c), and the old mosque (Eski Cami) in Edirne (805-816 AH./14031413 AD.), fig. (12-d) [26].
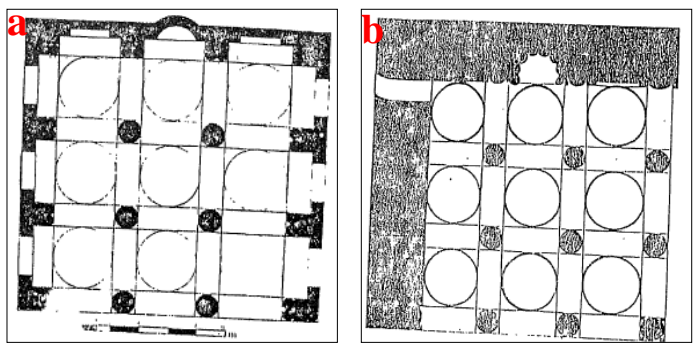

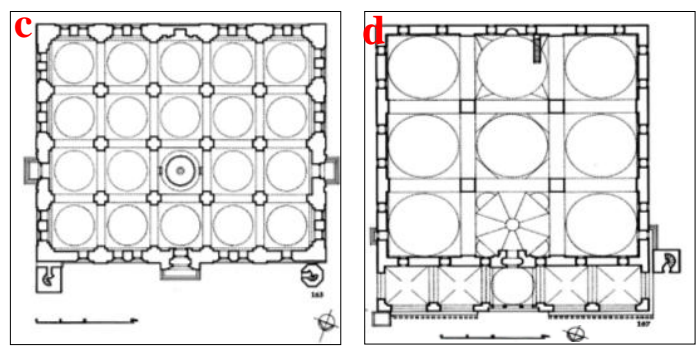

Figure (13) Shows ‥ plan of Balkh mosque (Golombek), b. plan of Tarmiz mosque (Hillenbrand), c. plan of Ulu mosque (Kuran), d. plan of Eski mosque (Kuran)

This pattern was known in the planning of mosques in Andalusia in the era of Taifas, such as the planning of the Bab al-Mardum mosque in Toledo (390 AH./999 AD.) and the Dabbaghin mosque in Toledo $\left(6^{\text {th }}\right.$ H./ $/ 12^{\text {th }}$ G.) century $[24,32]$. This pattern was also known in the planning of some mosques of the Islamic West, e.g., Darghout Pasha mosque who was the Tripoli governor (964-971 AH./1556-1563 AD.), Al-Nakhali mosque in Tripoli (1064 AH./ 1653 AD.), Al-Atiq mosque of Darnah (1081 AH./ 1670 AD.), and Ahmad Pasha al-Qaramanli mosque in Tripoli (1149 AH./1737 AD.) [3335]. Several hypotheses can be raised on the reasons for implementing this architectural planning in Al-Atiq mosque in Aljabalaw. The $\mathbf{1}^{\text {st }}$, this planning was known in the plans and architecture of Islamic religious establishments in Egypt since the Ikhshidid era and continued until the Ottoman era. Thus, the layout of Al-Atiq mosque in Aljabalaw might be influenced by these earlier models, especially the models of Aswan. The $\mathbf{2}^{\text {nd }}$, the period spent by the founder of the mosque, Sidi Mohamed Ahmed Al-Dandrawi, traveling between the different cities of Hijaz between delivering lessons and learn might play a role. He also spent a period in Sudan and his disciples were from different countries, including Egypt, Sudan, Somali, Hejaz, and the Levant. Thus, he was affected by some examples of mosques in those regions, including Al-Qabab mosque in Jazan, Abu Arish Governorate (1002 AH./1594 AD.), and Al-Musalla (Al-Ghamamah) mosque in Madinah (1255-1277 AH./1839-
1861 AD.) [36]. The $3^{\text {rd }}$ one consisting of a square or rectangular area divided into square areas covered with domes dominated most churches and monasteries during the Ottoman era and the $19^{\text {th }}$ century in Upper Egypt close to the place of the mosque under study, e.g., the shurches of Anba Bidaba monastery in Naj Hammadi, Mary gerges monastery in Mahrousa (Alballas) in Qena, fig. (14-a), Angel and Mjama monasteries in Naqada, fig. (14-b, c), In addition to other monasteries that affected adopting this planning in the mosque under study. [37,38].

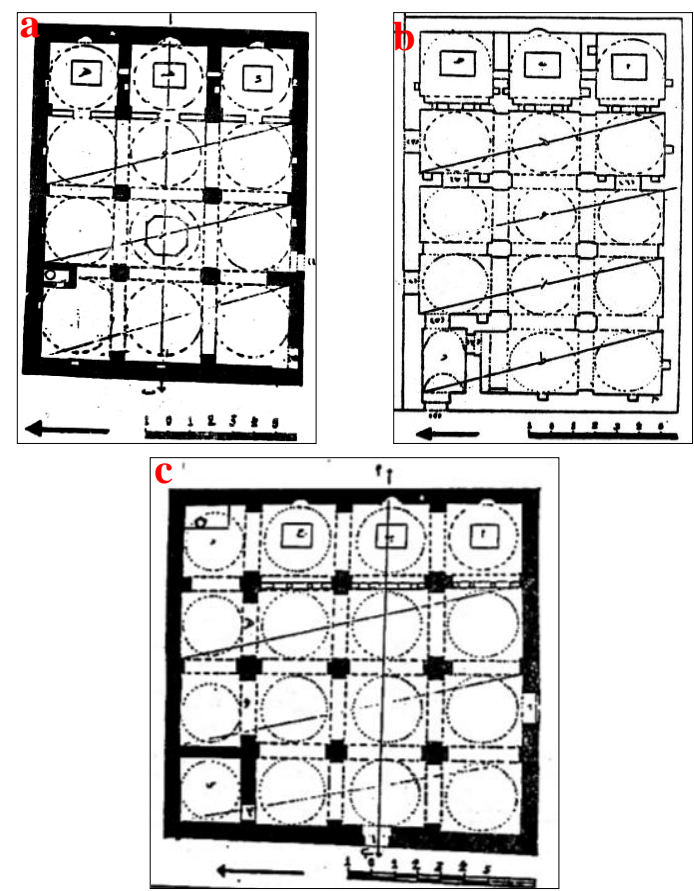

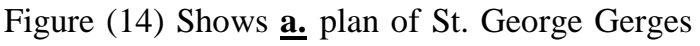
church in El Mahrousa (Ahmed Essa), b. plan of the church of the Angel monastery in Naqada (Ahmed Essa), c. plan of the church of the Mjama monastery in Naqada (Ahmed Essa),

The $4^{\text {th }}$ hypothesis, the planning of the domed ceiling is suitable environmentally for the climate of the hot region because it provides the moderate climate and humidity needed for the interior of the mosque. The architect handled the lack of ventilation and lighting resulting from this layout by creating a transverse lantern. He also succeeded in choosing the building materials that fit the nature of the place that is close to the River Nile. The environmental and climatic nature of the place is suitable for 
clay building materials because of the lack of heavy rain that causes this material to collapse. In other words, the mosque mainly relies on the surrounding environment. The $5^{\text {th }}$, the abundant trained manpower helped implement this type of coverage because the region is famous for building domes from ancient times [39].

\section{Conclusion}

The present paper handled the architecture of a rare mosque pattern, especially in Upper Egypt, i.e., the mosques with multiple domes coverage. It adopted the analytical-descriptive approach to handle the main problem in using this pattern in Upper Egypt that is hundreds of kilometers away from the capital with no political and commercial aspects. The mosque was designed to practice religious rites in addition to the rituals of the Dandarawiyya Ahmadiyya Order. It consisted of the block of Al musalla with multiple domes and cells for the murids (disciples) and the sheik. The researcher could identify a set of additions to the mosque and its annexes in a later period, including the second minaret, southwestern portico, portico of the courtyard, cells of the murids, kitchen, and store. The results showed that the planning of the mosque was affected by its prevalence in many close religious establishments and the trips and desires of the founder. The study showed the direct impact of the planning of most Christian churches in the Ottoman era and the $19^{\text {th }}$ century in Upper Egypt on the layout of Al-Atiq mosque. Moreover, the architect succeeded in planning the mosque in a way that is compatible with the surrounding environment in terms of style, treatments, or choosing building materials. The abundance of trained manpower affected the design of the domed layout of Al-Atiq mosque. Additionally, the diverse architecture affected the design of the mosque units. While the minbar has a pencil-like top (Ottoman style), the minaret followed the local style. The study recommends the registration of Al-Atiq mosque and its original annexes in Aljabalaw as an Islamic monument because of its history or unique planning.

\section{Endnotes}

(a) He was born in Cairo in (1291 AH./ 1874 AD.) and was a ruler of Egypt from the Alawiyya dynasty. He assumed the throne after the death of his father in (1309 AH./1892 AD.) continued till being removed from the throne in (1333 AH./1914 AD.). He died in (1363 AH./1944 AD.) [1,2]. (b) Some cities were known in Upper Egypt for being political centers, state headquarters, or trade centers in the $19^{\text {th }}$ century, such as Gerga, Akhmim, Esna, Qena, Naj Hammadi, and Dishna [3,4].

(c) The mosque is under registration by the Standing Committee of Antiquities.

(d) Inspectors of the Ministry of Antiquities documented the foundation text of the mosque above the southwestern entrance before destruction.

(e) This statement indicates a dhikr (prayer) of the Ahmadiyya Order [1].

(f) This Sufi order spreads in Yemen, Hijaz, Egypt, the Levant, India, Sudan, Somalia, Morocco, and other countries. It is attributed to Sheikh Ahmed Ibn Idris (1164-1254 AH./1750-1838 AD.) who was born in the Moroccan city of Fez and was taught by Sheikh Abd al-Wahhab al-Tazi. He traveled to Egypt and Mecca. He is attributed to Sharif al-Hassan bin Ali. He wrote many books, e.g., "aleaqd alnafis fi nazam jawahir altadris" (lit. Priceless Jewelry in the Order of Teaching Diamonds) $[6,7]$.

(g) It is an Upper Egyptian village located on the right bank of the Nile. It was known as the sacred city of the god Hator. Later, it was known by two civil names; Tarer and Tan Tarer. Additionally, its Coptic meaning denotes the willow tree, but its Arabic name is Dandara. Ancient Dandara was next to the Western Hajar of the Nile. Present Dandara was established by the Arabs on the western bank of the Nile to the west of Qena $[3,4,8]$.

(h) He was given the title of Sultan metaphorically. No historical resources mentioned the ruler who assumed the rule of the Idrisid state named Youssef [9].

(i) The Idrisid dynasty was established in (172 AH./788AD.) by Idris ibn Abdullah, known as Idris I attributed to Ali ibn Abi Talib. He escaped from the Battle of Fakh in Makkah (170 AH./786AD.) in which the Abbasid army killed many of Aal Albeit. He 
fled to Morocco and established his state. He founded Fez and made it the capital. The rule of the Idrisid extended to Tlemcen, Algeria. Their rule came to an end in (375 AH./985 AD.) [10,11].

(j) Sidi Muhammad Ahmad al-Dandrawi was called the Sultan perhaps because of his lineage to the Idrisid [13].

(k) It is made of clay and molded onto the floor directly and not on a wooden board $[17,18]$.

(l) The use of the semi-circular arch in many mosques spread in the villages of Upper Egypt in the Ottoman era and the $19^{\text {th }}$ century, such as the Abu Hajj Minaret in Luxor, Al-Omari mosque in Asfun, and Al-Omari mosque in Bahjoura [16].

(m) Abdi Bey mosque follows the layout of the mosques with multiple domes coverage. The architect covered the central square of the mosque with a lantern with an architectural modification that took place in the $19^{\text {th }}$ century, in which the dome was replaced with a lantern [19].

(n) Mudbrick is used in the construction of walls of not less than $50 \mathrm{~cm}$. It is used only in dry areas, so the wall was $1 \mathrm{~m}$ thick $[17,18]$.

(o) Baked brick is stronger and more durable than mud brick. Therefore, the architect used it in areas that need more strength and rigidity $[17,18]$.

(p) Minaret djawsaq of Al-Atiq mosque in Aljabalaw is similar to the early examples of minaret architecture, such as the minaret of Al-Omari mosque in Esna (474 AH./1081 AD.). Al-Atiq mosque is round, while Al-Omari mosque in Esna is an octagon, but they both have the djawsaq and windows. Similarly, the djawsaq in Al-Atiq mosque of Aljabalaw was similar to those of the minaret of Almashad Alqibly in Aswan $\left(5^{\text {th }} \mathrm{H} . / 11^{\text {th }} \mathrm{G}\right.$. century) and $\mathrm{Al}$ Jayyushi mosque in Cairo (478 AH./ 1085AD.) [22].

(q) Al-Aqmar mosque follows the traditional style of a courtyard and four port- icoes, but each portico is covered with domes [22].

(r) This layout was known as the multidomed or Bruce I model [25-27].

\section{References}

[1] Zydan, G. (2012). Tarajim mashahīr a-sharq fi alqarn altasi' a'shar (Bibliography of the celebrities of the East in the $19^{\text {th }}$ century), Kalimat Arabia Press, Cairo.

[2] Fahmy, Z. (2013). Șafwat al e'asr fi tarikh wa rwswm mashahì rijal mișr (The elect of the era in the history and figures of Egyptian celebrities), Kalimat Arabia Press, Cairo.

[3] Mubarak, A. (1888). Al-khitat al tawfiqiyya (Tawfiq's plans), Amiri Press, Cairo.

[4] Ramzi, M. (1994). Al qamws al gughrafi lilbilad al misria munzo 'ahd al qudama' al misriiyn 'iilaa sanat 1945 (The geographic dictionary of Egypt: From ancient Egypt to 1945), General Egyptian Book Organization, Cairo.

[5] Abudrahmn, M. (1996). dor al qabayil al'arabia fi saeid mișr munzo al fath al'iislamii hataa nihayat al dawla al fatimia (21-358 AH./ 641-969 AD.) (The role of the Arab tribes from the Islamic conquest to the Fatimid dynasty (21-358 AH./ 641-969 AD.), Madboly Press, Cairo.

[6] Al-Rashid, S. (n.d.). Eaqd al-dari annafis fi bad karamat wa manaqib 'aћmad ibn 'idris" (Priceless necklace on some dignities and virtues Ahmed ibn Idris), Dar Alkutub Alzahiria, Damascus.

[7] Alhafni, A. (1992). Almawsua alsawfia 'aelam altswf wa almunkirin ealayh wa alturuq alsuwfia (Sufi Encyclopaedia: Sufi celebrities, opponents, and orders), Dar Alrashad, Cairo.

[8] Al-Hamawi, Y. (1977). Mu'jam albuldān (Dictionary of countries), Dar Sadir, Beirut.

[9] Aleazawi, A. (2011). Almaghrib Alarabi fi alasr Al'iislami (Morocco in the Islamic era), Gulf Press, Amman.

[10] Nasrallah. S. (1987). Dawlat aladrsa fi almaghrib: Al'asr Aldhahabi, 172- 
223/788-835 (The Idrisid dynasty in Morocco: The golden era, 172-223/ 788-835, Dar Aln-ahda Alarabia, Beirut.

[11] Ismail, M. (1989). Aladrsa fi Almaghrib al'aqsaa 172-375 H. (The Idrisid dynasty in far Moroccol72-375 H.), Alfalah Press, Kuwait.

[12] Al-Dandrawi, A., (2006). Alwathiqa Albayda'a 1,: Al'usra Aldindirawiat takwin wa kian (The white document: Aldandrawi dynasty; formation and identity), Dar Alburaq, Beirut.

[13] Al-Hakim, S. (1994). 'awdat alwasil: Dirasat hawl Al'iinsan alsuwfii (Reunion: Studies on the Sufi), Dandara for Studies, Beirut.

[14] Al-Baqir, T., Hussein, Y., Ahmed, A. (2004). Mawsueat 'ahl aldhikr bi alsuwdan (Encyclopedia of ahl aldhikr in Sudan), Almajlis Alqawmii Lildhikr wa-ldhakirin, Khartoum.

[15] Abdel-Wahab, H. (1994). Tarikh almasajid al'athria (History of antique mosques), General Egyptian Book Organization, Cairo.

[16] Abdel-Raouf, G. (1985). Masajid Misr aleulya min alfath Al'arabii hataa nihayat al'asr al'uthmanii: Dirasa 'athriaa M'emaria (Upper Egyptian mosques from the Arab conquest to the late Ottoman era: An archaeological architectural study), M.A., Islamic Archaeology dept. Faculty of Archaeology, Cairo Univ., Egypt.

[17] Lucas, A., (1962). Ancient Egyptian materials and industries, Edward Arnold, USA.

[18] Waziry, Y., (2004). Ale'amara Al'iislamia wa albiya: alrawafid alty shakalat altaemir Al'iislamia (Islamic Architecture and environment: Fundamentals of Islamic establishment), Alam Almarefa, Cairo.

[19] Abu Al-Amayem, M. (2003). Athar Alqahra fi al'asr Al'uthmanii (Monuments of Cairo in the Ottoman Era), The Research Centre for Islamic History, Art and Culture, Istanbul.

[20] Abdel-Wahab, A. (2006). Altiraz alm 'uemari wa alfaniy li masajid Alqahra fi alqarn al thaleth 'ashr al hajrii "1215-1318 AH./1800-1899 AD." (The architectural and artistic pattern of Cairo mosques in the $13^{\text {th }} \mathrm{H}$. century 1215-1318 AH/1800-1899 AD), Ph.D., Islamic Archaeology dept., Faculty of Archaeology, Cairo Univ., Egypt.

[21] The Holy Qur'an, Surat Al-Isra (no. 17), Verse 56.

[22] Creswell, K. (2004). The Muslim architecture of Egypt (939-1171 A.D), Zahraa Alsharq, Cairo.

[23] El-Gendy, M. (2017). Dirasa atharia muemariali majmuet maazin bi muhafazat Al-gharbia: Ghayr manshura wa ghayr mosjla (An archaeological architectural study of a collection of Gharbia minarets: Unpublished and unregistered), J. of ArabArch., Vol. 18, pp. 557-596.

[24] Al-Haddad, M. (2004). Mawsu'at al'amara Al'iislamia fi Misr min alfath Al'uthmanii 'iilaa nihayat 'ahid Muhamad 'ali (Encyclopedia of Islamic architecture in Egypt from the Ottoman conquest to the tate Muhamad Ali dynasty) (923-1265 AH./15171848 AD.), Zahraa Alsharq, Cairo.

[25] Gabriel, A., (1926). Les mosques de Constantinople, Syria, Vol. 7 (4), pp. 353-419.

[26] Kuran, A. (1968). The mosque in early Ottoman architecture, University of Chicago Press, Chicago.

[27] Goodwin, G. (2003). A history of Ottoman architecture, Thames \& Hudson; Reissue ed., Great Britain.

[28] Duqmaq, A. (1994). Masajid Al 'iskandaria albaqiat bi al qarnayn al thany 'ashr wa al ththalith 'ashr b'aed Al hijra (Remaining mosques of Alexandria in the $12^{\text {th }}$ and $13^{\text {th }}$ H.), M.A., Islamic Archaeology dept., Faculty of Archaeology, Cairo Univ., Egypt.

[29] Darwish, M. (2017). Mawsueat Rashid: Al turath al eumranii (Rashid encyclopaedia: Urban heritage), Vol. 2, Moassaset oloum al-umaa lel estesmarat al thaqafia, Cairo 
[30] King, G. (1989). The Nine bay domed mosque in Islam, Madrider Mitteilungen, Vol XXX, pp. 332-390.

[31] Al-Haddad, M. (2006). Al mujmal fi Al tarikh wa al haddara wa al 'amara Al 'iislamia (Handbook of history, culture, and Islamic architecture), Zahraa Alsharq, Cairo.

[32] Maldonado, B. (2011). Eimarat al masajid fi Al andalus: Tliytala wa Ashbilia (Architecture of mosques in Al-Andalusia: Toledo and Sevilla) Abu Dhabi Culture and Heritage, Abu Dhabi.

[33] Abdo, A. (2001). Madinat Bariqa wa athareha Al 'iislamiatu (Cyrenaica and its Islamic Monuments), Dar Al'afaq Al'arabia, Cairo.

[34] Abdo, A. (2001). Dirasat fi al hadara wa al athar Al 'iislamia bi Lybya (Studies on the Islamic culture and monuments in Libya), Dar Al'afaq Al'arabia, Cairo.
[35] Bahnassi, S. (2004). Tarabulus al gharb: Modon trathya (Traboli the Weast: Heritage cities), Dar Al'afaq Al'arabia, Cairo.

[36] Abdul Ghani, M. (1998). Drasa al masajid al atharia bi Al madina al munawara (A study of the archaeological mosques in Medina), Al Rashid Press, Medina.

[37] Clarke, S. (1912). Christian antiquities: Nile valley contribution: A contribution towards the study of the ancient churches, Clarendon Press, Oxford.

[38] Ahmed. A. (2007). 'Amarat al kanisa fi Misr Al islamy (Architecture of the church in Islamic Egypt), Modern Academy Press, Cairo.

[39] Embaby, A. (1980). Al asquf al maqabiya wa that al qabab bi mintaqat Aswan Janub jumhuriat Misr Al 'arabia, (Doomed ceilings and that have dooms in Aswan city-South Egypt), J. of Studies and Research, Vol. 3, pp. 29-47. 